\title{
Education for environment: A useful concept
}

\author{
Giáo dục môi trường: Một khái niệm hũu dụng \\ Short communication
}

Giap, Binh Nga*

Faculty of Education and Psychology, Hanoi National University of Education, Hanoi, Vietnam

\begin{abstract}
By analyzing the relationship between sustainable development and education, the author developed the guidelines proposal for the practical work in environmental education and its application to guide instruction and research in Vietnam.
\end{abstract}

Trên cơ sở phân tích mối quan hệ tác động qua lại giữa giáo dục và sự phát triển bền vũng cũng nhu tiếp cận nhũng định nghĩa của một số tác giả khác về giáo dục môi trường. Tác giả đưa ra định hướng thực hành trong giáo dục môi truờng. Định huớng này ưng dụng trong giảng dạy và nghiên cứu giáo dục môi truờng tại Việt Nam.

Keywords: education, environmental education, sustainable development, practical works

\section{Relationship between sustainable development and education}

The former UN Secretary General, Kofi Annan, stated that the biggest challenge in this century will be to take an abstract-sounding idea - sustainable development - and turn it into reality for the entire world's people. The many would argue that this is essentially an educational enterprise. Building capacity for making decisions that considers the long-term future of economy, ecology and equity in society is a key task of education. In terms of education, Education for Sustainable Development (ESD) may be described as a continuous process that enables human beings to develop knowledge, skills, intelligence, creativity, wisdom, perspectives and values to motivate and empower people to work toward attaining such balance. In this process, the transition of individual potentials into excellent performance in various domains is very important (George et al., 2005).

Kofi Annan' idea provided a typical example of what that is referred to today as a "sustainability challenge". Fortunately there is also a growing number of international examples how to deal with such challenges in a sound way. Car-sharing cooperation e.g. started with small initiatives and developed to a nationwide organization is an example for the management of mobility. This example shows how initiatives of small groups can initiate innovation. The same process could also be started by activities of schools and educational institutions (George et al., 2005).
Societies generally expect educational systems to prepare young people for their future professional life and/or continued studies. The educational system is seen as having a socializing role and is expected to contribute to preparing young people to take up their responsibilities in helping to shape the complex society in which we all now live.

So ESD requires at least a holistic approach and then sustainable challenges need to be approached at a systemic level.

Education is a very complicated system. In order to find the optimum solution for education, careful research and decent investment are needed (Phong N.H et al., 2006). This paper will only provide with models and the way to approach the problem limited to the establishment of methodology, which will be a tool to support in studying and finding solution for education in Vietnam. The model consists of 3 layers. It is constructed from the components and many-sided relation (interaction) links. The kernel of the education system is a personality as a social individual with his own peculiarities of developing mind (Figure 1).

In general, all the components, both of the same and of the different layers, have impacts on each other reciprocally. This is a multi-sided relationship. However, we will study this interactive relationship with the purpose of understanding the influences on education, especially on personality as a social individual with his own peculiarities of developing mind. Different influences could be categorized into the groups such as direct indirect, mainsupplementary, and forward - backward. 
Based on the triangle shape "developing mind", the author developed the guidelines proposal for the practical work in environmental education.

\subsection{Working definition of environmental education}

Environmental education should be an integral part of the educational process, aimed at practical problems of an interdisciplinary character that build a sense of values, and contribute to public well-being. Its focus should reside mainly in the initiative of the learners and their involvement in action and be guided by both of the immediate and future subjects of concern (Stapp et all, 1998).

\subsection{Concept of environmental education}

Environmental education is a process aimed at developing a world population that is aware of and concerned about the total environment and its associated problems. This population has the attitudes, motivations, knowledge, commitment and skills to work individually and collectively towards solutions of current problems and the prevention of new ones (Stapp et all, 1998).

Awareness - to help individuals and social groups acquire an awareness of and sensitivity to the total environment and its allied problems;

Knowledge - to help individuals and social groups gain a variety of experiences with the total environment and to acquire a basic understanding of the environment, its associated problems and humanity's critical responsible presence and role in it;

Attitudes - to help individuals and social groups acquire social values, strong feelings of concern for the environment and the motivation for actively participating in its protection and improvement;

Skills - to help individuals and social groups acquire the skills for working toward the solution of environmental problems and to foster a dialogue between these groups;

Participation - to help individuals and social groups develop a sense of responsibility and urgency regarding environmental problems to ensure appropriate action to help solve these problems and avoid future problems.

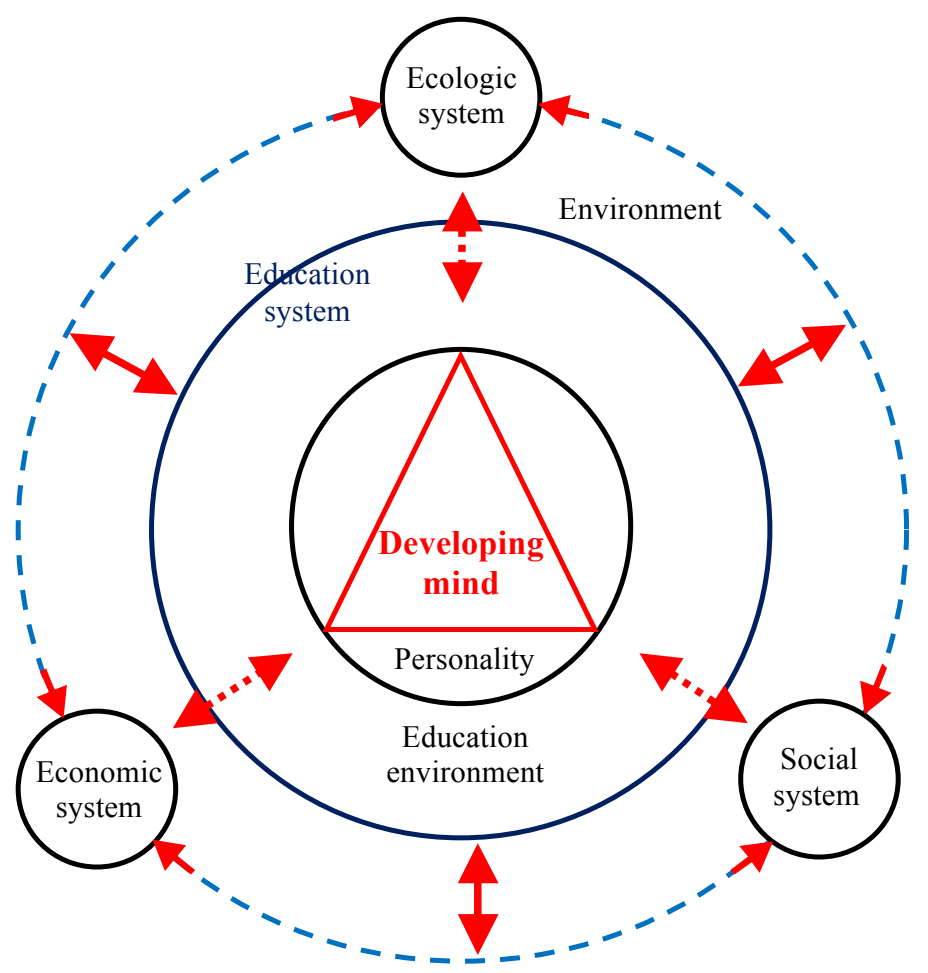

Figure 1. The model consist 3 layers: (1) External layer include ecologic, economic and social systems served as environment. (2) Education system is surrounded by educational environment. (3) Personality as a social individual with his own peculiarities of developing mind

\section{Guidelines proposed for the practical work in environmental education}

\subsection{General objectives}

- Knowing and analysing the operation of an entity are directly or indirectly related to Environmental Education (Natural Parks, naturalist organisations, civic centres, educational centres, educational learning camps, municipal services, hiking clubs, etc.).

- Presenting contributions/proposals in Environmental Education for the entity studied. 


\subsection{Considerations}

- Work in small groups (6-8 persons).

- Each group should select the entity they wish to analyse and study.

- It is important to consider the work being carried out within the framework of the entity: its objectives, the people to whom it is directed, its operating structure, its financing, its educational proposals, its resources, etc.

- It is advisable, once the group is situated in the cooperating entity, to make contributions/proposals that are aimed at improving, or including, educational action in Environmental Education.

- The proposals devised should be well defined, following the guidelines proposed. The work should be original and innovative.

- Being Environmental Education proposals, they should coherently and consistently integrate the conceptual, methodological and ethical components of Environmental.

- Education (Sleurs, 2008).

\subsection{Practical works}

(This guideline should not be thought of as a fixed proposal, but rather as one adaptable to the necessities of each group).

\section{PART I: Description of the entity}

- Typology

- Objectives

- Operating structure.

- Contents/ educational proposal.

- Methodology.

- Resources.

\section{PART II: Environmental Education proposal sum-} mary

- Implementation context of the proposal.

- Target public.
- Key concepts.

- Procedures to be developed.

- Attitudes and values to be encouraged.

- Expected timetable.

- Material resources and infrastructure.

\section{Development of the proposal}

- General objectives.

- Contents: conceptual, procedural, attitudinal and ethical issues.

- Detailed planning of the proposal: implementation process, development, etc.

- Material necessary for its implementation: guidelines, texts, images, games, work plans, sing or song, etc.

- Anticipation of new human resources, materials or infrastructure needed to carry out the proposal.

- Monitoring and evaluation of the proposal.

- Suggestions.

- Bibliography.

\section{References}

[1] Balan, G., Balan Elena V. D. (2005). Globalization and Education for Sustainable Development. Revista Economică, 72 .

[2] Phong, N.H., Hoa, N.P. (2006) Vietnamese Education From the Systematic Point of View.

[3] SLEURS, W. (2008). Competencies for ESD (Education for Sustainable Development) teachers. A framework to integrate ESD in the curriculum of teacher training institutes. Comenius, 2.

[4] Stapp, W.B., Bennett, D., Bryan Jr, W., Fulton, J., MacGregor, J., \& Nowak, P. (1998). The concept of environmental education. HUNGERFORD, Harold H.; BLUHM, William J.; VOLK, Trudi L, 33-36. 